DOI: $10.31073 / \mathrm{mivg} 201801-112$

Available (PDF): http://mivg.iwpim.com.ua/index.php/mivg/article/view/112

УДК 504.453

\title{
РЕТРОСПЕКТИВНИЙ АНАЛІЗ ДИНАМІКИ ЗМІН ЯКОСТІ ПОВЕРХНЕВИХ ВОД РІЧКИ ЗАХІДНИЙ БУГ
}

I.B. Гопчак, канд. геогр. наук

Національний університет водного господарства та природокористування, м. Рівне, Україна; e-mail:gopchak_igor@ukr.net

Анотація. Проведено порівняльну характеристику зміни інтегральних показників якості води р. Західний Буг протягом 50-річного періоду за критеріями мінералізаиії, трофо-сапробіологічними показниками та показниками вмісту специфічних речовин токсичної дії; досліджено зміну якості води за даними характеристиками протягом останніх десятиріч; виконано узагальнюючі спостереження і висновки. Встановлено, шо аналіз змін екологічного стану охарактеризував води Західного Бугу: у віддаленій ретроспективі-категорія 4, води ,задовільні ,, „слабко забруднені "; у середній ретроспективі категорія 5, води „, посередні", , помірно забруднені"; у близькій ретроспективі - категорія 4, води ,задовільні, , ,слабко забруднені".

Ключові слова: річка, поверхневі води, річковий басейн, екологічна оцінка, якість води, класифікаиія.

Постановка питання. На сьогодні надзвичайно актуальним єпитання оцінювання якості поверхневих вод. Необхідним є своєчасне проведення спостережень за якісним станом поверхневих вод басейнів річок та виконання аналізу з узагальненням інформації про стан водних об'єктів, прогнозування його змін та розробки науково обгрунтованих рекомендацій для прийняття відповідних управлінських рішень у галузі використання, охорони та відтворення водних ресурсів. Отримання такої інформації сприятиме: проведенню аналізу процесів, які відбуваються в басейні і створенню можливості прийняття державних рішень у справі використання поверхневих вод та їх належної охорони; прогнозуванню якісних i кількісних змін водних ресурсів у річковому басейні; проведенню оцінки впливу вмісту у поверхневих водах особливо шкідливих речовин; виявленню та оцінці природних та антропогенних факторів, що впливають на якість вод; накопиченню даних, які дозволять визначити стратегію охорони вод і покращення їх стану [1].

Аналіз останніх досліджень і публікацій. Оцінюванню якості води 3 різних позицій присвячено низку наукових досліджень. Аналіз наукових публікацій 3 екологічної оцінки якості води річок засвідчує про його проведення за басейновим та адміністративно-територіальним принципом. Вагомий внесок у методологію комплексної інтегральної оцінки екологічного стану басейнів річок зробили А.В. Яцик [2, 3], Й.В. Гриб [4].
Оцінка якості річкових вод та основні шляхи покращення екологічного стану малих річок басейну р. Західний Буг висвітлено у наукових працях $[5,6]$.

Мета досліджень - проаналізувати загальні тенденції змін якості води річки Західний Буг у ретроспективний період

Методика досліджень. Екологічне оцінювання якості поверхневих вод р. Західний Буг виконано за даними систематичних спостережень на основі екологічної класифікації якості поверхневих вод суші та естуаріїв України, яка включає набір гідрофізичних, гідрохімічних, гідробіологічних та інших показників, що відображають особливості складових водних екосистем. Вихідні дані відповідно до «Методики екологічної оцінки якості поверхневих вод за відповідними категоріями» були згруповані в три блоки показників: сольового складу води $\left(I_{1}\right)$; трофо-сапробіологічного (еколого-санітарного) блоку $\left(I_{2}\right)$; специфічних речовин токсичної дії $\left(I_{3}\right)$ [3]

Результати досліджень. Для 3'ясування загальних тенденцій змін якості води в річці Західний Буг протягом 50-річного періоду були обчислені підсумкові ретроспективні значення інтегральних екологічних показників за трьома блоками в період 31964 до 2013 року. Підсумковими інтегральні значення показників якості води трьох блоків вважаємо тому, що вони фактично $\epsilon$ часткою від поділу суми всіх сум величин категорій якості води на суму всіх сум кількості показників якості води кожного блоку. 
Таким чином, підсумкові інтегральні показники якості води можуть характеризувати 3 екологічних позицій якість води окремої річки в узагальненому виразі. При обччисленні значень інтегральних показників якості води, як стосовно окремих пунктів спостережень, так і стосовно певної річки в цілому, в першу чергу отримаємо округлені кількісні значення найбільш точних інтегральних показників: індексів сольового складу, трофо-сапробності та специфічних речовин токсичної дії. Вже на ї основі отримуємо кількісні значення субкатегорій, категорій і класів якості води і словесну характеристику екологічної якості води: клас і категорія якості за мінералізацісю (прісні, гіпо-олігогалинні), клас, група, тип за критеріями іонного складу, рівень трофності, зона сапробності за трофо-сапробіологічними критеріями [7].

Етап ретроспективної оцінки якості річкових вод за відповідними категоріями для окремих показників полягає у виконанні таких дій:

- найгірші, але допустимі, значення кожного показника якості води порівнюють 3 відповідними показниками якості води, наведеними в системі екологічних класифікацій якості поверхневих вод суші та естуаріїв України [3]. Таке зіставлення виконували шодо всіх наявних показників якості води на постійних пунктах спостережень в усі розрахункові періоди досліджень $(1964,1973,1984$, 1995, 2001, 2004, 2008, 2013 рр.). Подібний підхід дозволив визначити найгірші значення показників якості річкових вод басейнів Західного Бугу у віддаленій (1964, 1973), середній (1984, 1995) та близькій (2001-2013) ретроспективі і порівняти їх між собою;

- на основі проведеного зіставлення визначалися категорії якості води щодо кожного показника за найгіршими їх значеннями. Великою перевагою „Методики...” [3] $\epsilon$ те, що вона дозволяє абсолютні кількісні значення показників якості води (критеріï), оцінювані за гідрофізичними, гідрохімічними, гідробіологічними та бактеріологічними показниками, переводити в кількісні, але відносні та уніфіковані інтегральні показники якості води (класи, категорії, субкатегорії, індекси). У подальшому саме в межах цих категорій якості води встановлювали аб́солютні величини значень екологічної оцінки стосовно кожного показника якості води.

Підсумкові результати розрахунків найгірших значень показників якості води і об'єднана екологічна оцінка якості води р. Західний Буг за блоковими індексами сольового складу, трофо-сапробіологічних і специфічних показників за розрахункові періоди досліджень представлені в таблиці.

Ретроспективна екологічна оцінка якості води річки Західний Буг за найгіршими значеннями показників блокових індексів $\left(I_{1}, I_{2}, I_{3}\right)$ та величиною інтегрального екологічного індексу $\left(I_{E}\right)$

\begin{tabular}{|c|c|c|c|c|c|c|c|c|c|}
\hline \multirow{3}{*}{$\begin{array}{l}\text { № } \\
\text { 3/ח }\end{array}$} & \multirow{3}{*}{ Роки } & \multicolumn{8}{|c|}{ Значення індексів } \\
\hline & & \multirow[b]{2}{*}{$\mathrm{I}_{1}$} & \multirow[b]{2}{*}{$\mathrm{I}_{2}$} & \multirow[b]{2}{*}{$\mathrm{I}_{3}$} & \multirow[b]{2}{*}{$\mathrm{I}_{\mathrm{E}}$} & \multicolumn{2}{|c|}{ стан чистоти } & \multicolumn{2}{|c|}{ ступінь чистоти } \\
\hline & & & & & & $\begin{array}{c}\text { за } \\
\text { класом }\end{array}$ & за катег. & $\begin{array}{c}\text { за } \\
\text { класом }\end{array}$ & за катег. \\
\hline 1 & 1964 & 2,0 & 4,1 & 4 & 3,4 & добрі & добрі & чисті & $\begin{array}{c}\text { досить } \\
\text { чисті }\end{array}$ \\
\hline 2 & 1973 & 2,7 & 4,6 & 4,6 & 4,0 & $\begin{array}{l}\text { задо- } \\
\text { вільні }\end{array}$ & $\begin{array}{l}\text { задо- } \\
\text { вільні }\end{array}$ & $\begin{array}{c}\text { забруд- } \\
\text { нені }\end{array}$ & $\begin{array}{c}\text { слабко } \\
\text { забруднені }\end{array}$ \\
\hline 3 & 1984 & 3,7 & 6,0 & 5,2 & 5,0 & $\begin{array}{l}\text { задо- } \\
\text { вільні }\end{array}$ & $\begin{array}{l}\text { посе- } \\
\text { редні }\end{array}$ & $\begin{array}{c}\text { забруд- } \\
\text { нені }\end{array}$ & $\begin{array}{c}\text { помірно } \\
\text { забруднені }\end{array}$ \\
\hline 4 & 1995 & 2,7 & 5,4 & 5,3 & 4,5 & $\begin{array}{c}\text { задо- } \\
\text { вільні }\end{array}$ & $\begin{array}{l}\text { задо- } \\
\text { вільні }\end{array}$ & $\begin{array}{c}\text { забруд- } \\
\text { нені }\end{array}$ & $\begin{array}{c}\text { слабко } \\
\text { забруднені }\end{array}$ \\
\hline 5 & 2001 & 2,3 & 5,2 & 5,3 & 4,3 & $\begin{array}{l}\text { задо- } \\
\text { вільні }\end{array}$ & $\begin{array}{l}\text { задо- } \\
\text { вільні }\end{array}$ & $\begin{array}{c}\text { забруд- } \\
\text { нені }\end{array}$ & $\begin{array}{c}\text { слабко } \\
\text { забруднені }\end{array}$ \\
\hline 6 & 2004 & 2,3 & 5,4 & 4,0 & 3,9 & $\begin{array}{c}\text { задо- } \\
\text { вільні }\end{array}$ & $\begin{array}{l}\text { задо- } \\
\text { вільні }\end{array}$ & $\begin{array}{c}\text { забруд- } \\
\text { нені }\end{array}$ & $\begin{array}{c}\text { слабко } \\
\text { забруднені }\end{array}$ \\
\hline 7 & 2008 & 2,0 & 5,4 & 5,0 & 4,1 & $\begin{array}{l}\text { задо- } \\
\text { вільні }\end{array}$ & $\begin{array}{l}\text { задо- } \\
\text { вільні }\end{array}$ & $\begin{array}{c}\text { забруд- } \\
\text { нені }\end{array}$ & $\begin{array}{c}\text { слабко } \\
\text { забруднені }\end{array}$ \\
\hline 8 & 2013 & 2,7 & 4,8 & 5,0 & 4,2 & $\begin{array}{c}\text { задо- } \\
\text { вільні }\end{array}$ & $\begin{array}{l}\text { задо- } \\
\text { вільні }\end{array}$ & $\begin{array}{c}\text { забруд- } \\
\text { нені }\end{array}$ & $\begin{array}{c}\text { слабко } \\
\text { забруднені }\end{array}$ \\
\hline
\end{tabular}


Сольовий режим басейну Західного Бугу тісно пов'язаний 3 місцевими фізико-географічними умовами i їх особливостями. Тому межі гідрохімічних змін в них достатньо добре співпадають 3 межами фізико-географічних зон, загальна мінералізація та вміст головних іонів зростають у напрямку з півночі на південь - від зони Полісся до Лісостепової зони.

Сольовий склад води Західного Бугу формується в умовах підвищеної вологості і визначається впливом карбонатних і гіпсових порід, які залягають в основі їх водозборів. Тому вода Західного Бугу за природними умовами відповідає, згідно класифікації О.О. Альокіна [8], гідрокарбонатному класу, групі кальцію, II-III типу, CII--II. За 50-річний період досліджень найгірші значення мінералізації не перевищували - 800 мг/дм³ [9].

Джерелами надходження важких металів в поверхневі води $\epsilon$ мінеральні речовини гірських порід, потрапляння їх 3 атмосфери, стічні води, фізико-хімічний стан поверхневих вод. Нафтопродукти і СПАР, які зустрічаються в поверхневих водах, це типові представники господарської діяльності на водозборах річок. Задля об'єктивної оцінки динаміки змін інтегральних показників якості води за критеріями вмісту специфічних речовин токсичної дії i виявлення джерел їх надходження в поверхневі води річкового басейну необхідні детальні гідрохімічні та токсикологічні дослідження на обраних ділянках річки 3 урахуванням природних умов і особливостей господарської діяльності на водозборі. На жаль, ми мали в розпорядженні дуже незначну кількість інформації про наявність у річковій воді специфічних речовин токсичної дії, особливо це стосується двох перших розрахункових періодів. У 1964 р. ми мали можливість оцінювати якість річкової води Західного Бугу тільки за вмістом заліза загального, а в 1973 р. ще за поодинокими даними вмісту міді, цинку, хрому загального, марганцю, фенолів, СПАР і нафтопродуктів. У 1984 i 1995 рр. додатково з'яв.ляється незначна кількість інформації про вміст свинцю і нікелю. Тобто динаміку змін якості води за критеріями вмісту специфічних речовин токсичної дії можна простежити тільки по залізу загальному, сполуки якого містяться в усіх грунтах і породах басейну $[7,10,11]$.

Проаналізувавши динаміку змін інтегральних показників якості поверхневих водр. Західний Буг у межах України протягом 19642013 рр. (Рис. 1) варто відмітити, що якість води за найгіршими величинами відповідає:

- сольовий блок, в основному, 2-3 категорія, II клас, „добрі”, „чисті” води. Найбруднішими в цьому відношенні $€$ поверхневі води в 1984 р., які належать до 4 категорії, III класу якості (верхня ділянка, від с. Сасів до м. Кам'янка-Бузька) і оцінюються як „задо-

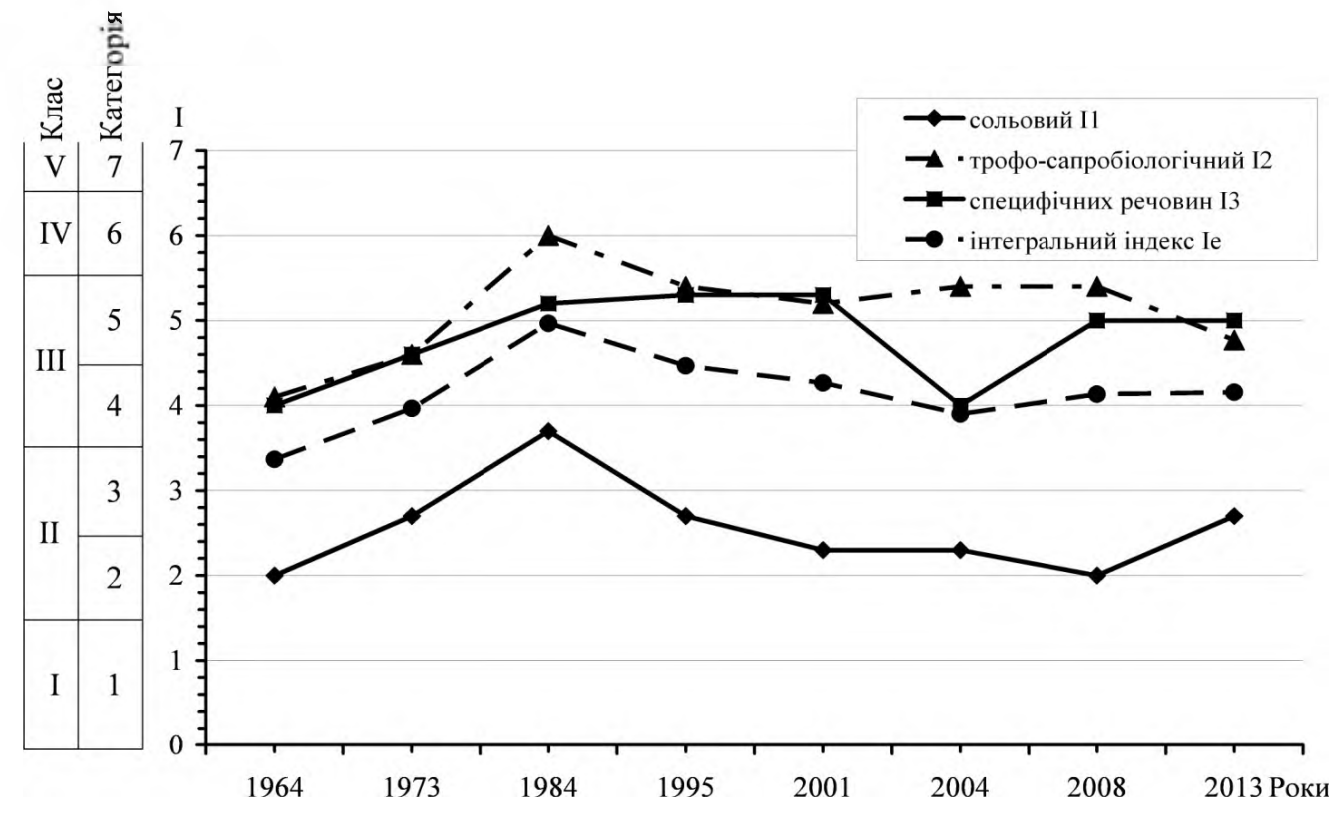

Рис. 1. Динаміка змін величин інтегральних показників якості води p. Західний Буг за найгіршими значеннями критеріїв I1, I2, I3 та Ie впродовж 1964-2013 років 
вільні”, „слаббо забруднені” води. Основною причиною такого явища $\epsilon$ високі концентрації хлоридів і сульфатів відмічені у воді на верхній (с. Сасів - м. Кам'янка-Бузька), середній (м. Червоноград - м. Устилуг) i нижній (с. Ягодин - с. Грабове) ділянках річки за зазначений період. На всьому протязі від с. Сасів (поблизу витоку) до с. Грабове (на кордоні з Білоруссю) вода р. Західний Буг $\epsilon$ гідрокарбонатно-кальцієвою, II-III типу [8];

- трофо-сапробіологічні показники протягом розрахункового періоду - 4-5 категорія, III клас „задовільні”, „забруднені”, а в 1984 р. - 6 категорія, IV класу якості „погані”, „брудні”. Такий високий рівень трофності Західного Бугу можна пояснити лише одним: великим вмістом речовин, які $\epsilon$ чинниками високої потенційної біологічної продуктивності річок, проте водночас й фактором низької якості вод. Проведений аналіз показав, що за вмістом нітритного і нітратного азоту та фосфатів води Західного Бугу та його приток належали, як правило, до категорій 6 i 7 ("дуже брудні", “дуже погані");

- специфічні речовини токсичної дії 4-5 категорія, III клас „задовільні”, „забруднені" води. Навіть у далекій ретроспективі якість поверхневих вод, у межах Волинського Полісся, за величиною $I_{3}$ розрахована тільки по вмісту заліза загального, оцінюється 4-5 категоріями, III класом якості, оскільки значні концентрації заліза загального в річках області обумовлені специфічними особливостями природних умов формування якісного складу річкових вод Волині.

Отже, якість води річки протягом 50-річного періоду спостережень, оцінювана $з$ екологічних позицій за підсумковими значеннями інтегральних показників якості води трьох блоків, знаходилася в діапазоні від 2 до 6 категорії, від „дуже добрих", „чистих” до „поганих”, „брудних” вод. У той же час підсумкові екологічні індекси $\left(I_{E}\right)$ для найгірших ї значень варіюють у межах 3,4-5,0 і оцінюються від „добрих”, „досить чистих" до „посередніх", „помірно забруднених" вод, тобто в межах II і ІІІ класів якості.

За досліджуваний період якість води за найгіршим вмістом специфічних речовин токсичної дії в руслі Західного Бугу погіршилася на 1 категорію.

Аналіз зміни підсумкових значень інтегральних показників якості води блоків сольового складу, трофо-сапробіологічних і специфічних речовин токсичної дії, за їх найгіршими значеннями, в період від 1964 до 2013 pp. в р. Західний Буг показав таке:
- найкращі значення підсумкових інтегральних показників якості води сольового блоку були зафіксовані в 1964 і 2008 pp. i відповідали категорії 2, II клас $\left(I_{1}=2,0\right)$. В 1973, 1995 і 2013 рр. якість води вже належала за блоком Il до категорії $3\left(I_{1}=2,7\right)$, а в 1984 т р. -4 категорія $\left(I_{1}=3,7\right)$, II і III класам. Простежується поступове (з 1964 до 1984 рр.) погіршення якості води, приблизно на 2 категорії, а в 1995 р. ступінь забруднення мінеральними речовинами знижується майже на 1 категорію (в 1984 р. $I_{1}=3,7$, в 1995 р. $I_{1}=2,7$ );

- дещо інша картина відбувалася 3 блоком трофо-сапробіологічних показників, від першого до третього розрахункових рівнів відмічається погіршення якості води (особливо за найгіршими величинами, $1964 \mathrm{p}$. $I_{2}=4,1$; в 1973 p. $I_{2}=4,6$; в 1984 p. $\left.I_{2}=6,0\right)$. У 1995 р. порівняно з 1984 р., зафіксовано покращення якості річкових вод на 1 категорію;

- порівняльна характеристика відносно блоку специфічних речовин токсичної дії показала, що в 1964 і 1973 рр. води за величиною $I_{3}$ знаходились у межах 4 категорії якості $\left(I_{3}=4,0-4,6\right)$, а в 1984 і 1995 pp. відбулося погіршення якості води до 5 категорії $\left(I_{3}=5,2-5,3\right)$, при цьому якість води залишається у межах III-го класу якості.

Протягом досліджуваного періоду величини коливалися в діапазоні:

- блок сольового складу $\left(I_{1}\right)-2-4$ категорій;

- трофо-сапробіологічний блок $\left(I_{2}\right)$ 4-6 категорій;

- блок специфічних показників $\left(I_{3}\right)$ 4-5 категорій

Динаміка змін підсумкових величин інтегральних показників якості поверхневих вод p. Західний Буг, за їх найгіршими значеннями, протягом 50-річного періоду досліджень свідчить про: прогресуюче їх забруднення мінеральними речовинами (приблизно на 2 категорії з 1964 до 1984 р.); значне збільшення забруднення за трофо-сапробіологічними компонентами (на 2 категорії з 1964 до 1984 р.); неухильне збільшення забруднення поверхневих вод токсичними речовинами (більш як на 1 категорію 3 1964 по 1995 р.). У наступні періоди досліджень процес погіршення якості річкової води змінюсться на тенденцію покращення.

Висновки. Проведений аналіз змін підсумкових значень інтегральних екологічних індексів трьох блоків показників $\left(I_{1}, I_{2}, I_{3}\right)$, а також сумарного екологічного індексу $\left(I_{E}\right)$, у період з 1964 по 2013 рр. (таблиця) дає формальні підстави охарактеризувати екологічний стан і тенденції змін якості води в річці Західний Буг так: 
- на всіх ділянках річки води „добрі”, „досить чисті”, II клас якості зафіксовано лише в 1964 році $\left(I_{E}=3,4\right)$;

- у 1973 р. води верхньої, середньої і нижньої ділянок річки за середніми і найгіршими величинами $I_{E}$ класифікуються як ,задовільні”, „слабко забруднені”, III клас якості $\left(I_{E}=4,0\right)$;

- у 1984 р. річкові води трьох ділянок характеризувалися за найгіршими величинами $I_{E}$ як „посередні", „помірно забруднені" $\left(I_{E}=5,0\right)$;

- у 1995-2013 роках води Західного Бугу за найгіршими значеннями цих індексів були за станом „задовільні”, „слабко забруднені” $\left(I_{E}=3,9-4,5\right)$.

Відмічені тенденції зміни якості річкових вод у басейні Західного Бугу протягом багато- річного періоду спостережень відбуваються в результаті взаємовпливу природних і антропогенних чинників на екологічний стан поверхневих вод. До того ж в тих місцях, де спостерігався значний вплив антропогенних чинників, якість води була, як правило, гіршою, а трофність і сапробність вищою.

Виконане екологічне оцінювання якості поверхневих вод p. Західний Буг може бути використане для визначення основних напрямків природоохоронної діяльності щодо оздоровлення екологічної обстановки водних об' єктів у межах басейну або його ділянки, оцінки ефективності проведених водоохоронних заходів і встановлення екологічних нормативів якості води.

\section{Бібліографія}

1. Екологічна очінка якості поверхневих вод украӥнської частини басейну річки Західний Буг / Гопчак I.B та ін. // Вода: проблемы и решения: материаль Х науч.-практ. конф., 2. Днепропетровск, - Дніпропетровськ: «Гамалія», 2012. 272 c.

2. Методика встановлення і використання екологічних нормативів якості поверхневих вод суиі та естуаріӥв України /В.Д. Романенко та ін. - Київ: 3 АТ «ВІПОЛ», 2001. 48 c.

3. Методика екологічної оцінки якості поверхневих вод за відповідними категоріями В.Д. Романенко та ін.- Київ: Символ-Т, 1998. $28 \mathrm{c}$.

4. Гриб Й. В., Клименко М. О., Сондак В.В. Відновна гідроекологія порушених річкових та озерних систем(гідрохімія, гідрологія, управління): навч. посіб. Т. 1. Рівне: РДТУ, 1999. 348 с.

5. Забокрицька М. Р. Очінка сучасного стану якості річкових вод басейну р. Західний Буг (у межсах Волинської області). Регіональні екологічні проблеми: збірник наукових прачь. Київ: ВГЛ «Обрії», 2002. С. 143-145.

6. Клименко Н. А., Вознюк Н. Н., Лихо Е. А. Особенности формирования качества поверхностных вод р. Западный Буз. Материалы VII Международной конферениии. Вариава, 2005. C. $193-200$.

7. Встановлення і використання екологічних нормативів якості поверхневих вод Волинської області. Заключний звіт УНДІВЕП / Яиик А.В. та ін. - Київ, 2003. С.109-151.

8. Алёкин О.А. Основы гидрохимии. Ленинград: Гидрометиздат, 1970. 444 c.

9. Гопчак I.В. Аналіз динаміки змін якості води головних річок Волинської області. // Вісник Національного університету водного господарства та природокористування. Рівне, 2005. Bun. 4(32). C. $71-78$.

I0.Яџык А.В., Гопчак И.В. Экологическая оченка качества бассейнов Западного Буга и Припяти (в пределах Волынской области). Современное состояние, проблемы и перспективы использования трансграничных водных объектов: Материаль Международного Водного Форума. Минск: Бэлсэнс, 2006. С. 52.

11. ЯџыкА.В., Чернявская А.П., ГопчакИ.В. Экологическая оченкаповерхностныхвод Украины (на примере Вольнской области). Вода: экология и технология: Седьмой Международный конгресс (ЭКВАТЕК-2006). Москва: СИБИКО Интернэинл, 2006. Ч. 1. С. 1 47-148.

\section{References}

1. Gopchak, I.V., Basiuk, T.O., Bondar, A.E., \& Hrysiuk, T.O. (2012). Ekolohichna otsinka yakosti poverkhnevykh vod ukrainskoi chastyny baseimu richky Zakhidnyi Buh [Environmental assessment surface water quality of the Ukrainian part river basin Western Bug7. Voda: problemy y reshenyia: materyaly X nauch.-prakt. konf. Dnepropetrovsk.: Hamaliya, 56-60. [in Ukrainian].

2. Romanenko, V.D., Jukinskyi, V.M., Oksiyuk, O.P., Yatsyk, A.V., Chernyavska, A.P., \& Vasenko, O.G. et al. (2001). Metodyka vstanovlennia $i$ vykorystannia ekolohichnykh normatyviv yakosti poverkhnevykh vod sushi ta estuariiv Ukrainy [Methodology for the establishment and use of ecological norms of quality of surface waters of land and estuaries of Ukraine]. Kyiv: VIPOL. [in Ukrainian].

3. Romanenko, V.D., Jukinskyi, V.M., Oksiyuk, O.P., Yatsyk, A.V., Chernyavska, A.P., \& Vasenko, O.G. et al. (1998) Metodyka ekolohichnoi otsinky yakosti poverkhnevykh vod za vidpovidnymy 
katehoriiamy [Methodology of ecological assessment of surface water quality according to the relevant categories ]. Kyiv: Symvol-T. [in Ukrainian].

4. Hryb, Y. V., Klymenko, M. O., \& Sondak, V.V. (1999). Vidnovna hidroekolohiia porushenykh richkovykh ta ozernykh system(hidrokhimiia, hidrolohiia, upravlinnia) [Restorative hydroecology of disturbed river and lake systems (hydrochemistry, hydrology, management)]. (Vol. 1-3; Vol.1). Rivne: Rivnen. derzh. tekhn. un-t. [in Ukrainian].

5. Zabokrytska, M. R. (2002). Otsinka suchasnoho stanu yakosti richkovykh vod baseinu r. Zakhidnyi Buh (u mezhakh Volynskoi oblasti) [Assessment of the current status of river basin quality in the western basin (within the Volyn region)]. Kyiv: Obrii, 143-145. [in Ukrainian].

6. Klymenko, N. A., Vozniuk, N. N., Lykho, E. A. Osobennosty formyrovanyia kachestva poverkhnostnykh vod $r$. Zapadnyi Buh [Features of the formation of the quality of surface water of the Western Bug River]. Materialy VII Mezhdunar. konf. Varshava, 193-200. [in Ukrainian].

7. UNDIVEP. (2003). Vstanovlennia i vykorystannia ekolohichnykh normatyviv yakosti poverkhnevykh vod Volynskoi oblasti [Establishment and use of environmental quality standards for surface waters in the Volyn region].: Zvit pro NDR (zaklyuchnyy, 2003 r.). № DR 0102U005904. Kyiv. [in Ukrainian].

8. Alekin, O.A. (1970). Osnovy hydrokhimii [Basics of hydrochemistry]. Leningrad: Hidrometizdat. [in Ukrainian].

9. Hopchak I.V. (2005). Analiz dynamiky zmin yakosti vody holovnykh richok Volynskoi oblasti [Analysis of the dynamics of water quality changes in the main rivers of the Volyn region]. Visnyk Natsionalnoho universytetu vodnoho hospodarstva ta pryrodokorystuvannia. 4(32), 71-78. [in Ukrainian].

10. Yatsyk, A.V., \& Gopchak, I.V. (2006). Ekolohycheskaya otsenka kachestva basseinov Zapadnoho Buha y Prypiati (v predelakh Volynskoi oblastiy) [Environmental quality assessment of the Western Bug and Pripyat basins (within the Volyn region)]. Materyaly Mezhdunarodnoho Vodnoho Foruma «Sovremennoe sostoianye, problemy y perspektyvy yspolzovanyia transhranychnykh vodnykh obektov». Mynsk: Belsens, 52. [in Russian].

11. Yatsyk, A.V., Cherniavskaia, A.P., Gopchak, I.V. (2006). Ekolohycheskaia otsenka poverkhnostnykh vod Ukrayny (na prymere Volynskoi oblasty) [Environmental assessment of surface waters of Ukraine (on the example of the Volyn region)]. Sedmoi Mezhdunarodnyi konhress "Voda: ekolohyia y tekhnolohyia» (EKVATEK-2006). Moskva: SIBIKO Interneshnl, 147-148. [in Russian].

\section{Ретроспективный анализ динамики изменений качества поверхностных вод реки Западный Буг}

Проведена сравнительная характеристика изменения интегральных показателей качества воды р. Западный Буг в течение 50-летнего периода по критериям минерализачии, трофо-сапробиологическим показателями и показателями содержсания специфических веществ токсического действия; исследовано изменение качества воды по данным характеристикам в течение последних десятилетий; выполнены обобщаюиие наблюдения и выводы. Установлено, что анализ изменений экологического состояния охарактеризовал воды Западного Буга: в отдаленной ретроспективе - категория 4, воды "удовлетворительные", "слабо загрязненные»; в средней ретроспективе - категория 5, воды "посредственные", "умеренно загрязненные"; в близкой ретроспективе - категория 4, воды "удовлетворительные", "слабо загрязненные".

\section{Retrospective analysis of the dynamics of changes}

I.V. Gopchak

\section{in the surface water quality in the Western Bug River}

The comparative characteristic of the change integral indicators of water quality in the Western Bug River during the 50-year period is carried out according to the criteria of mineralization, trophic-saprobiological indices and indicators of the content of specific substances of toxic action; the water quality change has been investigated according to these characteristics during the last decades; generalized observations and conclusions were made. It was established that the analysis of changes in the ecological status was characterized by the waters of the Western Bug: in the remote retrospective - category 4, the water is "satisfactory", "poorly polluted"; in the middle retrospective - category 5, water "mediocre", "moderately polluted"; in the near retrospect - category 4, water "satisfactory", "poorly polluted". 